\title{
Convective transport over the central United States and its role in regional $\mathrm{CO}$ and ozone budgets
}

\section{Citation}

Thompson, Anne M., Kenneth E. Pickering, Russell R. Dickerson, William G. Ellis, Daniel J. Jacob, John R. Scala, Wei-Kuo Tao, Donna P. McNamara, and Joanne Simpson. 1994. "Convective Transport over the Central United States and Its Role in Regional CO and Ozone Budgets." Journal of Geophysical Research 99 (D9): 18703. doi:10.1029/94jd01244.

\section{Published Version}

doi:10.1029/94JD01244

\section{Permanent link}

http://nrs.harvard.edu/urn-3:HUL.InstRepos:14121769

\section{Terms of Use}

This article was downloaded from Harvard University's DASH repository, and is made available under the terms and conditions applicable to Other Posted Material, as set forth at http:// nrs.harvard.edu/urn-3:HUL.InstRepos:dash.current.terms-of-use\#LAA

\section{Share Your Story}

The Harvard community has made this article openly available.

Please share how this access benefits you. Submit a story.

\section{Accessibility}




\title{
Convective transport over the central United States and its role in regional $\mathrm{CO}$ and ozone budgets
}

\author{
Anne M. Thompson, ${ }^{1}$ Kenneth E. Pickering, ${ }^{2}$ Russell R. Dickerson, ${ }^{3}$ \\ William G. Ellis Jr., ${ }^{3}$ Daniel J. Jacob, ${ }^{4}$ John R. Scala, ${ }^{2}$ Wei-Kuo Tao, ${ }^{1}$ \\ Donna P. McNamara, 5 and Joanne Simpson ${ }^{1}$
}

\begin{abstract}
We have constructed a regional budget for boundary layer carbon monoxide over the central United States $\left(32.5^{\circ}-50^{\circ} \mathrm{N}, 90^{\circ}-105^{\circ} \mathrm{W}\right)$, emphasizing a detailed evaluation of deep convective vertical fluxes appropriate for the month of June. Deep convective venting of the boundary layer (upward) dominates other components of the $\mathrm{CO}$ budget, e.g., downward convective transport, loss of $\mathrm{CO}$ by oxidation, anthropogenic emissions, and $\mathrm{CO}$ produced from oxidation of methane, isoprene, and anthropogenic nonmethane hydrocarbons (NMHCs). Calculations of deep convective venting are based on the method of Pickering et al. [1992a] which uses a satellitederived deep convective cloud climatology along with transport statistics from convective cloud model simulations of observed prototype squall line events. This study uses analyses of convective episodes in 1985 and 1989 and $\mathrm{CO}$ measurements taken during several midwestern field campaigns. Deep convective venting of the boundary layer over this moderately polluted region provides a net (upward minus downward) flux of $18.1 \times 10^{8} \mathrm{~kg} \mathrm{CO}$ month $^{-1}$ to the free troposphere during early summer, assuming the June statistics are typical. Shallow cumulus and synoptic-scale weather systems together make a comparable contribution (total net flux $16.2 \times 10^{8} \mathrm{~kg}$ $\mathrm{CO}$ month ${ }^{-1}$ ). Boundary layer venting of $\mathrm{CO}$ with other $\mathrm{O}_{3}$ precursors leads to efficient free tropospheric $\mathrm{O}_{3}$ formation. We estimate that deep convective transport of $\mathrm{CO}$ and other precursors over the central United States in early summer leads to a gross production of $0.66-1.1 \mathrm{Gmol} \mathrm{O}_{3} \mathrm{~d}^{-1}$ in good agreement with estimates of $\mathrm{O}_{3}$ production from boundary layer venting in a continental-scale model [Jacob et al., 1993a, b]. In this respect the central U.S. region acts as a "chimney" for the country, and presumably this $\mathrm{O}_{3}$ contributes to high background levels of $\mathrm{O}_{3}$ in the eastern United States and $\mathrm{O}_{3}$ export to the North Atlantic.
\end{abstract}

\section{Introduction}

Large amounts of tropospheric $\mathrm{O}_{3}$ are transported off the North American continent to the global troposphere, particularly in the summer season [Parrish et al., 1993; Jacob et al., 1993a]. This $\mathrm{O}_{3}$ contributes to the enhanced background $\mathrm{O}_{3}$ in northern hemisphere middle latitudes seen in the tropospheric residual derived from TOMS and SAGE satellite data [Fishman et al., 1990]. Much of the exported $\mathrm{O}_{3}$ must be in the free troposphere rather than the boundary layer because $\mathrm{O}_{3}$ in the boundary layer, though abundant, has a lifetime of only a few days against deposition. A model simulation for a typical summer season by Jacob et al. [1993a] shows that about half the $\mathrm{O}_{3}$ generated photochem-

\footnotetext{
${ }^{1}$ NASA Goddard Space Flight Center, Greenbelt, Maryland.

${ }^{2}$ Universities Space Research Association, Laboratory for Atmospheres, NASA/GSFC, Greenbelt, Maryland.

${ }^{3}$ Department of Meteorology, University of Maryland, College Park.

${ }^{4}$ Division of Applied Sciences and Department of Earth and Planetary Sciences, Harvard University, Cambridge, Massachusetts.

${ }^{5}$ Applied Research Corporation, Landover, Maryland.

Copyright 1994 by the American Geophysical Union.

Paper number 94JD01244.

0148-0227/94/94JD-01244\$05.00
}

ically in the boundary layer over the United States is vertically transported to the free troposphere. Ozone precursors $\left(\mathrm{NO}_{x}\right.$, hydrocarbons, $\mathrm{CO}$ ) are also transported to the free troposphere. Indeed, we have shown through analysis of individual events in the urban-influenced midwestern United States that free tropospheric $\mathrm{O}_{3}$ formation in cloud outflow regions may be $2-4$ times greater than in the absence of deep convection [Dickerson et al., 1987; Luke et al., 1992; Pickering et al., 1988, 1989, 1990, 1992b; Scala et al., 1993]. Jacob et al. [1993a] estimate that $4 \mathrm{Gmol} \mathrm{O}_{3} \mathrm{~d}^{-1}$ are produced from precursors exported from the boundary layer over the United States, which is roughly equal to the amount of $\mathrm{O}_{3}$ exported directly from the boundary layer.

These results indicate the need for closer examination of regional vertical transport of $\mathrm{O}_{3}$ and its precursors. This paper reports a study of the vertical transport for $\mathrm{CO}$ over the central United States and evaluation of other processes (advection, photochemistry, surface emissions) to derive a regional $\mathrm{CO}$ budget for early summertime conditions. The objectives of the analysis are twofold: (1) to assess the relative importance of deep convective venting of $\mathrm{CO}$ in a large region typical of the summertime rural United States (section 2) and (2) to estimate the amount of $\mathrm{O}_{3}$ produced by this deep convection (section 3 ). The upward deep convective flux is by far the largest single term in the boundary layer CO budget, but net upward deep convective flux may not be 
Average Deep Convective Cloud Coverage (\%)

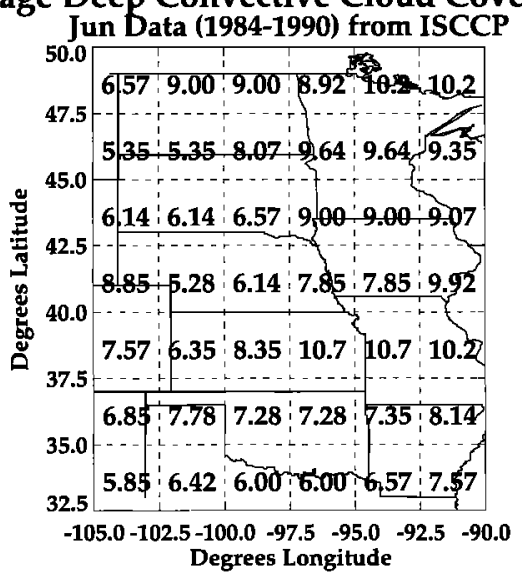

Figure 1. Monthly mean coverage by deep convective clouds for June, based on International Satellite Cloud Climatology Project (ISCCP) for 1984-1990.

much larger than the combined effect of two other venting mechanisms, shallow cumulus clouds and frontal systems. Implications of the net convective $\mathrm{CO}$ flux for the regional $\mathrm{O}_{3}$ budget are impressive, however. We estimate an $\mathrm{O}_{3}$ formation rate of $0.66-1.1 \mathrm{Gmol} \mathrm{O}_{3} \mathrm{~d}^{-1}$, suggesting that convective venting of $\mathrm{CO}$ and other precursors plays a major role in free tropospheric $\mathrm{O}_{3}$ formation.

\section{Evaluation of Regional CO Budget}

We have estimated the terms of a regional $\mathrm{CO}$ budget for the central United States $\left(32.5^{\circ}-50^{\circ} \mathrm{N}, 90^{\circ}-105^{\circ} \mathrm{W}\right)$ boundary layer. This region extends from near the Canadian border southward to the approximate limit of the temperate climate zone. Outside the western border are the Rocky Mountains, where orographic lifting dominates transport. The regional boundary layer budget can be represented by the following equation:

$$
F_{i}+F_{d}+F_{s}+P=F_{o}+F_{u}+L+R .
$$

The fluxes are as follows: $F_{u}$ is the upward deep convective flux from the boundary layer to the free troposphere; $F_{d}$ is the downward convective flux from the free troposphere to the boundary layer; $F_{i}$ is the horizontal flux into the region; and $F_{o}$ is the horizontal flux out of the region. The term $F_{s}$ is the surface flux, which in this case includes the regional anthropogenic emission of $\mathrm{CO}$, the biogenic source of $\mathrm{CO}$, and $\mathrm{CO}$ deposition. $P$ represents the photochemical production of $\mathrm{CO}$ by oxidation of $\mathrm{CH}_{4}$, isoprene, and short-lived anthropogenic hydrocarbons. $L$ is the photochemical loss of $\mathrm{CO}$ and $R$ is the budget residual. The following subsections describe the calculation of each component in (1).

\subsection{Regional Upward and Downward Deep Convective Fluxes}

The statistical-dynamical approach for computing $F_{u}$, the upward mass flux, was developed by Pickering et al. [1992a] to estimate the regional convective transport of $\mathrm{CO}$ from biomass burning in the Amazon Basin. It is based on the following simple equation:

$$
F_{u}=f A_{g} C H M .
$$

The calculation is made in terms of kilograms per month for a single grid cell and summed over all cells in a region. The ISCCP (International Satellite Cloud Climatology Project [Rossow and Schiffer [1991]) grid cell $\left(2.5^{\circ} \times 2.5^{\circ}\right)$ is used; $f$ is the monthly mean fractional deep convective cloud cover for the grid cell. $C$, the fraction of boundary layer air convectively transported to the free troposphere per unit time in a prototype storm, is derived from the Goddard Cumulus Ensemble Model [Tao and Simpson, 1993; Tao et al., 1993] results for three prototype midwest events [Pickering et al., 1992b; Tao et al., 1993; Scala et al., 1993]. $H$ is the average depth of the boundary layer taken to be $1.5 \mathrm{~km}$ [from Holzworth, 1964]. $M$ is the mass concentration of boundary layer $\mathrm{CO}$ in the grid cell based primarily on observations made by the University of Maryland air chemistry group. $A_{g}$ is the grid cell area $\left(\mathrm{km}^{2}\right)$. Calculations were performed for 42 ISCCP grid cells and individual convective fluxes were summed over the region $\left(32.5^{\circ}-50^{\circ} \mathrm{N}\right.$ and $90^{\circ}-$ $105^{\circ} \mathrm{W}$ ).

Figure 1 shows the grid of ISCCP mean deep convective cloud cover values averaged over the Junes of 1984 through 1990. Deep convective clouds are defined by ISCCP as those clouds with tops at pressures less than 440 mbar and with optical depths greater than 23 . Values of mean deep convective cloud cover range from slightly over $5 \%$ over portions of the Dakotas and Nebraska to about $10 \%$ in northern Minnesota and across Missouri and eastern Kansas. These values are likely underestimates of actual deep convective cloud coverage because much of this region has a nocturnal thunderstorm maximum [Rasmusson, 1971] and the ISCCP cloud identification algorithm uses visible (daytime) satellite imagery to determine cloud optical depth. For simplicity we have assumed uniform day and night deep convective cloud cover. Calibration errors in the ISCCP data may also lead to a small underestimate of the daytime convective cloud coverage [Klein and Hartmann, 1993].

We hoped to derive a more reliable June climatology derived from the U.S. Air Force real-time nephanalysis (RTNEPH) for the years 1984-1992 because RTNEPH includes nighttime data. Deep convective cloud cover from RTNEPH over the study region was less than from ISCCP. It was not possible to compare the two data sets rigorously because satellite imagery is archived in RTNEPH less frequently (every 6 hours) than in ISCCP (3-hour frequency). There is also less validation information for RTNEPH than for ISCCP, so we used the latter for deep convective climatology.

The central United States in early summer is convectively active with storms ranging in scale from isolated thunderstorms to large mesoscale convective complexes (MCCs). Individual convective cells pump air from the boundary layer to the free troposphere over a range of rates, although some cells draw air from only above the boundary layer [e.g., Pickering et al., 1988]. The three squall lines used as prototype events for the present analysis represent mediumsized linear mesoscale convective systems, covering much more area than isolated storms but much less than the large quasi-circular MCCs. The result should be a more reliable budget than one based on isolated events (not detectable from satellite) or on MCCs which are beyond the scope of the cloud-scale model. Convective transport statistics for the three squall line events are shown in Table 1 . Simulations were performed using a two-dimensional version of the 
Table 1. Model Statistics for Prototype Events

\begin{tabular}{|c|c|c|c|c|c|}
\hline Event & $\begin{array}{c}\text { Fraction of BL Air } \\
\text { Transported to Free } \\
\text { Troposphere }\end{array}$ & $\begin{array}{c}\text { Time Period, } \\
\text { hours }\end{array}$ & $\begin{array}{l}\text { Transport } \\
\text { Rate/hour }\end{array}$ & $\begin{array}{l}\text { Fraction of 2- to } 7-\mathrm{km} \\
\text { Air Transported to } \mathrm{BL}\end{array}$ & $\begin{array}{l}\text { Transport } \\
\text { Rate/hour }\end{array}$ \\
\hline \multicolumn{6}{|c|}{ PRESTORM } \\
\hline June 10,1985 & 0.712 & 6.5 & 0.109 & 0.278 & 0.046 \\
\hline \multicolumn{6}{|c|}{ PRESTORM } \\
\hline June 26,1985 & 0.511 & 3.0 & 0.170 & 0.161 & 0.054 \\
\hline \multicolumn{6}{|c|}{$N D T P$} \\
\hline June 29, 1989 & 0.439 & 2.5 & 0.176 & 0.145 & 0.058 \\
\hline
\end{tabular}

BL, boundary layer; PRESTORM, Preliminary Regional Experiment for STORM; NDTP, North Dakota Thunderstorm Project.

Goddard Cumulus Ensemble Model. Wind fields generated by the cloud model were used in a tracer advection scheme to compute the redistribution of tracers from each of several vertical layers. Details of the simulations are described by Pickering et al. [1992b], Tao et al. [1993], and Scala et al. [1993]. The redistribution of tracer is computed for the convective region of each storm, which roughly corresponds to the area defined as deep convective cloud by ISCCP. Model results are summarized for upward transport from layers within the boundary layer and for downward transport from layers comprising the $2-$ to $7-\mathrm{km}$ range into the boundary layer. The downward flux calculation represents the descending rear inflow typically found in convective systems over this region. The upward distribution of boundary layer air is shown in Figure 2 for a convective event from the North Dakota Thunderstorm Project (NDTP). Some boundary layer air is transported as high as $15-16 \mathrm{~km}$, and a peak in the redistributed tracer appears from 8 to $10 \mathrm{~km}$. Table 1 shows model statistics for this NDTP storm and for two systems that occurred over Oklahoma and Kansas during the Preliminary Regional Experiment for STORM (PRESTORM) Central in 1985. The fraction of boundary layer air transported to higher altitudes throughout the lifetime of the system is given along with the length of the simulation and

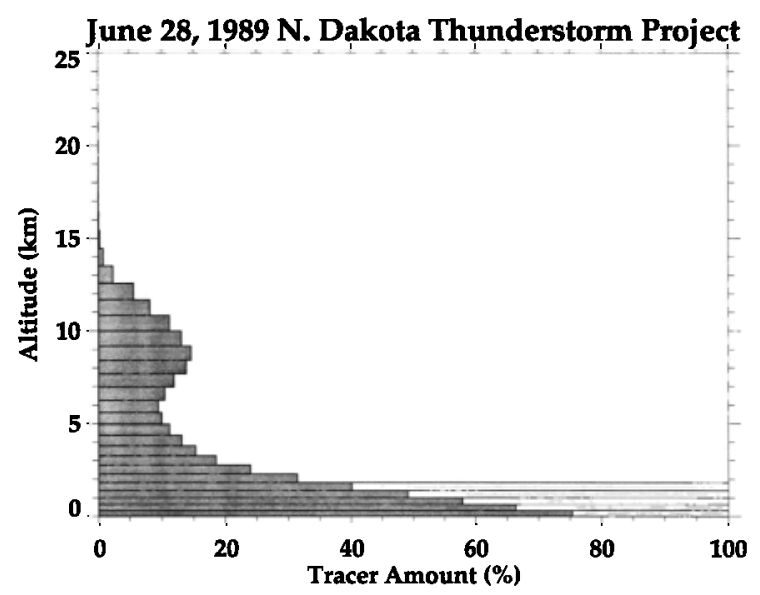

Figure 2. Vertical redistribution of boundary layer tracer for the June 28, 1989, North Dakota Thunderstorm Project (NDTP) convective event as simulated by the Goddard Cumulus Ensemble Model. Values of tracer were initially set to $100 \%$ in each of the five sublayers comprising the boundary layer, as indicated by the open bars. Shaded bars represent the distribution after 2.5 hours of simulated convective redistribution. the transport rate (in terms of percent per hour). Rates for the three storms ranged from about $11 \%$ per hour to almost $18 \%$ per hour. These values provide an upper and lower limit for the estimate of upward deep convective flux. Table 1 also shows downward transport (fraction of air in the 2- to 7-km layer transported into the boundary layer) and transport rates ranging from 4.6 to $5.8 \% \mathrm{~h}^{-1}$. These values are used as upper and lower limits on the downward flux calculation.

Routine $\mathrm{CO}$ measurements are performed in urban areas in the region. There are many cities in the region (10 metropolitan areas with at least 500,000 population), but their total area is a relatively small fraction of total land area in the region. Therefore urban $\mathrm{CO}$ measurements are not representative of the study region and we adopt rural $\mathrm{CO}$ data collected during field studies as more typical. The University of Maryland air chemistry group made CO measurements in four airborne midwest field experiments between 1985 and 1989: (1) PRESTORM in June 1985, based in Oklahoma City [Luke et al., 1992; Dickerson et al., 1987]; (2) Trace Gas Profiles III, based in Boulder, Colorado, and Grand Forks, North Dakota, in June 1986 [Luke, 1990]; (3) the Cloud Chemistry, Cloud Physics Organization (3CPO) project in June 1988 based in Champaign-Urbana, Illinois [Ryan et al., 1990]; and (4) the NDTP in June and July 1989 based in Bismarck, North Dakota [Dickerson et al., 1994; Poulida and Dickerson, 1993]. Collection of CO data is described by Luke et al. [1992]; further details of the CO instrument are given by Dickerson and Delany [1988]. In addition, $\mathrm{CO}$ data for the 2- to 7-km layer over Arkansas and Missouri are available from Boatman et al. [1989]. CO data for the boundary layer and the $2-$ to $7-\mathrm{km}$ layer from these experiments are summarized in Table 2 . Occasional inadvertent urban plume measurements were excluded in the selection of data from these flights. Some of the free tropospheric measurements may contain influence of convection. Rural boundary layer CO ranges from 115 parts per billion by volume (ppbv) over North Dakota to 177 ppbv over Illinois with more uniform conditions in the 2- to 7-km layer, 107 ppbv over Arkansas to 137 ppbv over Minnesota. We bilinearly interpolated the measurements (Figures $3 a$ and $3 b$ ) on the ISCCP grid so that a boundary layer and middle troposphere $\mathrm{CO}$ mixing ratio were available for each grid cell used in the equation (2) calculation.

Figure $4 a$ shows the computed values of convective mass flux from the boundary layer to the free troposphere for each grid cell. Lower limit values are as small as $\sim 4 \times 10^{7} \mathrm{~kg} \mathrm{CO}$ month ${ }^{-1}$ over the western Dakotas, where the boundary layer air is relatively clean. Upper limit values approach 24 
Table 2. Summary of CO Measurements

\begin{tabular}{|c|c|c|c|c|c|c|c|}
\hline \multirow[b]{2}{*}{ Project } & \multirow[b]{2}{*}{ Location } & \multicolumn{3}{|c|}{ Boundary Layer $[\mathrm{CO}]$, ppbv } & \multicolumn{3}{|c|}{$2-7 \mathrm{~km}[\mathrm{CO}], \mathrm{ppbv}$} \\
\hline & & Mean & s.d. & Observation & Mean & s.d. & Observation \\
\hline PRESTORM & Oklahoma, Kansas & 159 & 45 & 54 & 109 & 18 & 619 \\
\hline \multirow{3}{*}{ Trace Gas Profiles III } & Colorado & 158 & 24 & 6 & 118 & 36 & 58 \\
\hline & North Dakota & $\ldots$ & $\ldots$ & $\ldots$ & 131 & 18 & 10 \\
\hline & Minnesota & $\cdots$ & $\cdots$ & $\cdots$ & 137 & 21 & 16 \\
\hline $3 \mathrm{CPO}$ & Illinois & 177 & 52 & 149 & 122 & 32 & 487 \\
\hline NDTP & North Dakota & 115 & 18 & 501 & 120 & 19 & 1263 \\
\hline AIRS & Central United States & $655^{*}$ & $\cdots$ & $\cdots$ & $\cdots$ & $\cdots$ & $\cdots$ \\
\hline
\end{tabular}

Note that aircraft CO observations are 30- and 60-s means. AIRS, aerometric information retrieval system.

* Monthly mean for June (1987-1991) over 19 suburban and 2 rural surface stations.

$\times 10^{7} \mathrm{~kg}$ month $^{-1}$ over Missouri and eastern Kansas where convective cloud cover and boundary layer pollution both maximize. Summing over the $\mathbf{4 2}$ grid cells gives a total upward convective flux over the region of between $38.4 \times$ $10^{8}$ and $62.0 \times 10^{8} \mathrm{~kg} \mathrm{month}^{-1}$.

Additional upward flux from regions containing urban plumes must still be considered. Surface $\mathrm{CO}$ measurements from the U.S. Environmental Protection Agency's aerometric information retrieval system (AIRS) were summarized for the states comprising the central United States. Data are available for 42 urban stations, 19 suburban stations, and 2 rural stations (located near urban areas). We averaged the June data for 5 years (1987-1991) from the suburban and rural sites to yield an average surface $\mathrm{CO}$ mixing ratio for the urban plumes in the region ( $655 \mathrm{ppbv})$. We estimated an average $\mathrm{CO}$ mixing ratio for the $1.5-\mathrm{km}$ depth of the boundary layer containing an urban plume by averaging the surface value and the average free tropospheric mixing ratio (117 ppbv) to obtain 387 ppbv. The additional upward convective flux from the urban plumes was estimated with (2) for the 10 metropolitan areas in the region with greater than 0.5 million people. We assumed an average plume width of $50 \mathrm{~km}$ (based on average metropolitan area dimensions) and an average plume length of $100 \mathrm{~km}$ (based on data for the Oklahoma City urban plume [Pickering et al., 1989]) to obtain an "urban" upward convective flux of 1.2-1.9 $\times 10^{8}$ $\mathrm{kg}$ month $^{-1}$. Adding this amount to the upward deep convective flux in rural areas gives a total upward flux of between $39.6 \times 10^{8}$ and $63.9 \times 10^{8} \mathrm{~kg} \mathrm{month}^{-1}$. Note that the urban contribution to $F_{u}$ is only $2-3 \%$ of the rural value.

A modified form of (2) was used to estimate the downward flux $\left(F_{d}\right)$ of $\mathrm{CO}$ from the middle troposphere into the boundary layer for each grid cell. In this calculation the variable $C$ is now the fraction of the mass in the 2- to $7-\mathrm{km}$ layer that is transported into the boundary layer; $M$ is the average mass concentration of $\mathrm{CO}$ in the 2- to $7-\mathrm{km}$ layer; and $H$ is the $5-\mathrm{km}$ depth of this layer. Figure $4 \mathrm{~b}$ shows the computed downward flux, $F_{d}$, for each grid cell. The smallest values, $\sim 4.5 \times 10^{7} \mathrm{~kg}$ month $^{-1}$, occur over the western Dakotas. Upper limits are approximately $12 \times 10^{7} \mathrm{~kg}$ month $^{-1}$ over northern Minnesota where middle tropospheric $\mathrm{CO}$ is a maximum and over Missouri and eastern Kansas where the convective cloud cover maximizes. Summing over all the grid cells in the region gives a total downward convective flux of between $29.8 \times 10^{8}$ and $37.5 \times$ $10^{8} \mathrm{~kg} \mathrm{month}^{-1}$.

\subsection{Surface Fluxes: CO Emission and Deposition}

Anthropogenic $\mathrm{CO}$ emissions for the region are taken from the National Acid Precipitation Assessment Program (NAPAP) 1985 emission inventory [Saeger et al., 1989]. Emission values are given on a $1 / 6^{\circ}$ latitude by $1 / 4^{\circ}$ longitude grid for a summer weekday. Emissions were summed over the region and adjusted for Saturdays and Sundays to arrive at a monthly total emission $\left(7.6 \times 10^{8} \mathrm{~kg} \mathrm{month}^{-1}\right)$. Pierson et al. [1990] and Buhr et al. [1992] have suggested that the NAPAP emission inventory underestimates $\mathrm{CO}$ emissions. Model simulations by Jacob et al. [1993b] with the NAPAP mobile source $\mathrm{CO}$ emission doubled show a better match with $\mathrm{CO}$ observations at some stations and worse comparisons at others.

A small quantity of $\mathrm{CO}$ is emitted from forests. Upward fluxes from forests have been measured, ranging from $1.2 \times$ $10^{11}$ molecules $\mathrm{cm}^{-2} \mathrm{~s}^{-1}$ over boreal forest [Ritter et al., 1994] to $4 \times 10^{11}$ molecules $\mathrm{cm}^{-2} \mathrm{~s}^{-1}$ over tropical rain forest [Kirchhoff and Marinho, 1990]. For the temperate forests in the central United States we have assumed the mean of these two values $\left(2.6 \times 10^{11}\right.$ molecules $\left.\mathrm{cm}^{-2} \mathrm{~s}^{-1}\right)$. Forests comprise $12.6 \%$ of the land area in the region, based on the vegetation database of Matthews [1983]. We calculate a biogenic emission of $1.0 \times 10^{8} \mathrm{~kg}^{-1}$ month $^{-1}$ for the region.

For nonforest vegetation types, downward flux (deposition) exceeds emissions, as $\mathrm{CO}$ is taken into the soil. We calculate the deposition of $\mathrm{CO}$ over the remaining $87.4 \%$ of the land area using a deposition velocity of $0.02 \mathrm{~cm} \mathrm{~s}^{-1}$ [Seiler, 1974] and the boundary layer CO data, yielding $1.7 \times$ $10^{8} \mathrm{~kg}$ month ${ }^{-1}$. Therefore the net biogenic flux is $0.7 \times 10^{8}$ kg month ${ }^{-1}$ downward.

\subsection{Photochemical Production and Loss}

$\mathrm{CO}$ is produced in the boundary layer through oxidation of many hydrocarbons. We estimate $\mathrm{CO}$ production from oxidation of $\mathrm{CH}_{4}$, isoprene, and short-lived anthropogenic hydrocarbons. The rate of $\mathrm{CO}$ production from $\mathrm{CH}_{4}$ is computed using

$$
d[\mathrm{CO}] / d t=k_{3}\left[\mathrm{CH}_{4}\right][\mathrm{OH}]
$$

where $k_{3}$ is the rate constant for the reaction of methane with the hydroxyl radical $(\mathrm{OH})$. We assumed a $90 \% \mathrm{CO}$ yield from this reaction. A mean $\mathrm{CH}_{4}$ mixing ratio of $1683 \mathrm{ppbv}$ (average of boundary layer samples taken during PRESTORM) is used along with a model estimate of average daytime $[\mathrm{OH}]$ of $4 \times 10^{6}$ molecules $\mathrm{cm}^{-3}$ [Pickering et al., 
1990] to calculate $\mathrm{CO}$ production in (3) to be $2.2 \times 10^{8} \mathrm{~kg}$ month ${ }^{-1}$ over the region.

We estimate a regional isoprene emission for the month of June, $0.42 \mathrm{Tg}$ isoprene from data presented by Placet et al. [1990]. Assuming a 60\% CO yield from isoprene oxidation [Lurmann et al., 1986; Zimmerman et al., 1978], we compute a CO production of $5.2 \times 10^{8} \mathrm{~kg}$ month $^{-1}$. To estimate CO production from reactive anthropogenic nonmethane hydrocarbons, we took the NAPAP summer weekday emission inventory values for short-lived hydrocarbons and assumed an oxidation $\mathrm{CO}$ yield of $30-50 \%$, based on experimental $\mathrm{CO}$ yield data from Hanst et al. [1980]. After adjustments for weekends were made, these assumptions yield a $\mathrm{CO}$ production rate over the region of $0.3-0.5 \times 10^{8} \mathrm{~kg} \mathrm{month}^{-1}$. Summation of the three components of $\mathrm{CO}$ production from hydrocarbon oxidation yields $7.8 \times 10^{8} \mathrm{~kg}$ month $^{-1}$, approximately the same as direct anthropogenic CO emissions.
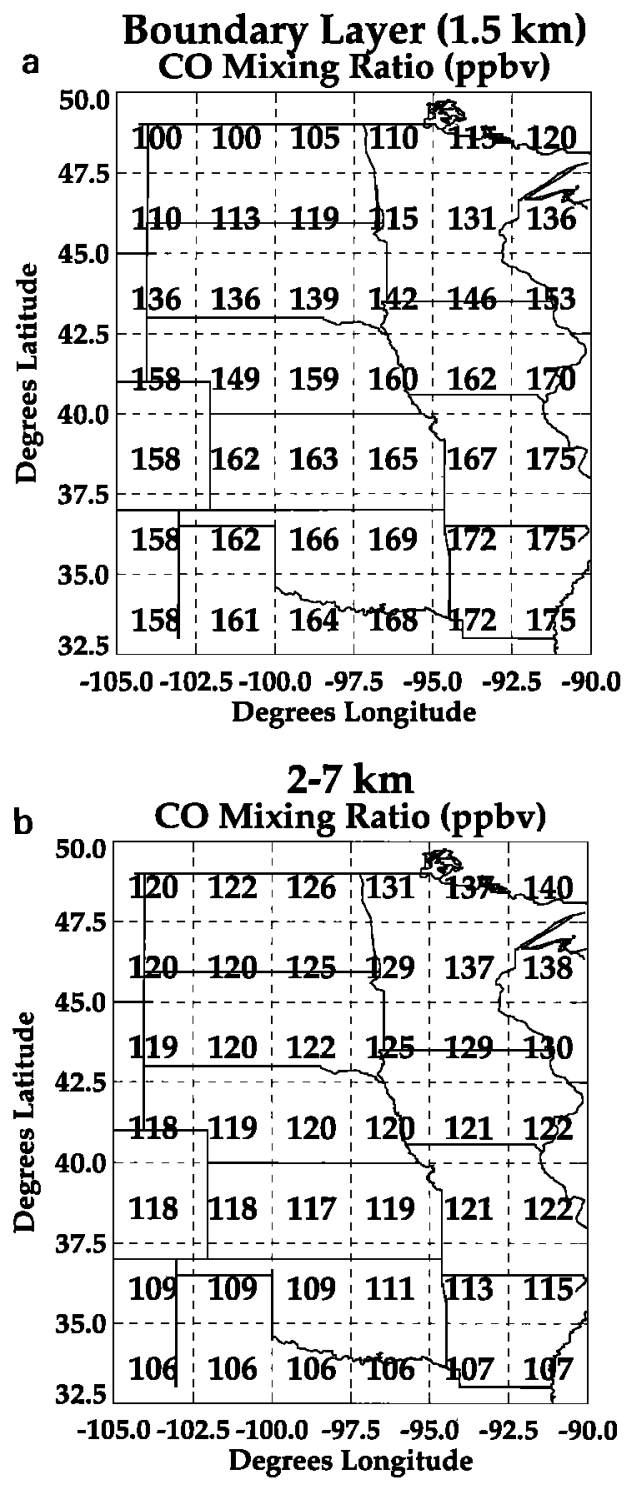

Figure 3. Measured June CO data interpolated onto International Satellite Cloud Climatology Project (ISCCP) grid: (a) boundary layer $(0-1.5 \mathrm{~km})$ measurements and (b) measurements taken from 2 to $7 \mathrm{~km}$. a Convective Mass Flux of $\mathrm{CO}$

Out of Boundary Layer $\left(\mathbf{1 0}^{7} \mathbf{~ k g} /\right.$ month)

$$
\begin{aligned}
& \begin{array}{ll|l:l:l:l|l}
50.0 & 4.55 & 6.23 & 6.54 & 6.80 & 8.19 & 8.55 \\
\hline
\end{array}
\end{aligned}
$$

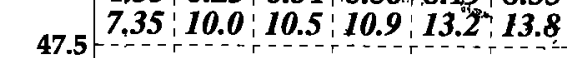

$$
\begin{aligned}
& \begin{array}{|l|l|l|l|l|l|l|}
\hline 4.28 & 4.40 & 6.98 & 8.06 & 9.18 & 9.24 \\
\hline
\end{array}
\end{aligned}
$$

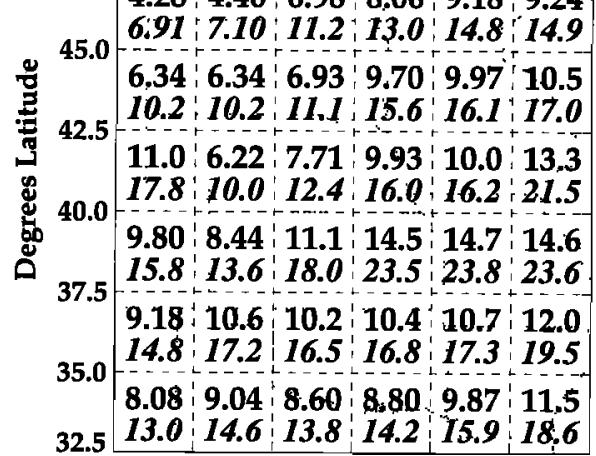

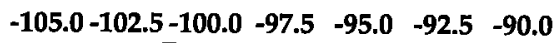

$$
\begin{aligned}
& \text { Degrees Longitude }
\end{aligned}
$$

b Convective Mass Flux of $\mathrm{CO}$

Into Boundary Layer $\left(10^{7} \mathrm{~kg} /\right.$ month)

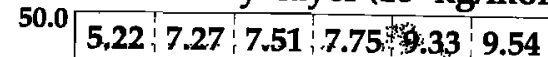

$$
\begin{aligned}
& 47.56 .58: 9.17,9.47,9.77: 11.9 .12 .0 \\
& \begin{array}{|l|l|l|l|l|l|l|l|l|l|l|l|l|l|l|l|l|}
\hline 4.46 & 4.46 & 7.01 & 8.64 & 9.18 & 8: 9 \% \\
\hline
\end{array}
\end{aligned}
$$

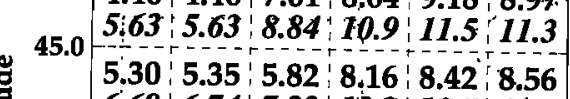

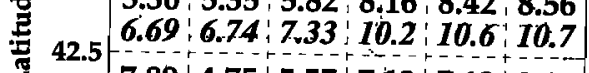

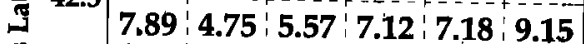

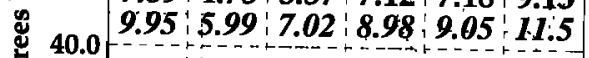

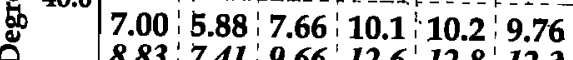

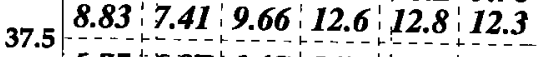

$$
\begin{aligned}
& \begin{array}{|c|c|c:c:c:c}
6.05 & 6.87 & 6.43 & 6.55 & 6.73 & 7.59 \\
\hline
\end{array} \\
& \begin{array}{l|l|l|l|l|l|l|}
\mathbf{3} 5.0 & 7.63 & 8.67 & 8.11 & 8.26 & 8.49 & 9.57 \\
\hline & 5.18 & 5.69 & 5.31 & 5.31 & 5.87 & 6.77 \\
\hline
\end{array} \\
& \begin{array}{|l|l|l|l|l|l|l|l|l|l|l|l|}
\hline 5.18 & 5.69 & 5.31 & 5.31 & 5.87 & 6.77 \\
\hline
\end{array} \\
& \begin{array}{l|l|l|l|l|l|l|l|}
32.5 & 6.54 & 7.18 & 6.70 & 6.70 & 7.40 & 8.53 \\
\hline
\end{array} \\
& \text {-105.0-102.5-100.0 -97.5 }-95.0 \quad-92.5 \quad-90.0 \\
& \text { Degrees Longitude }
\end{aligned}
$$

Figure 4. Computed convective vertical fluxes of $\mathrm{CO}$ (kilograms per month) for June: (a) upward fluxes from the boundary layer to the free troposphere, (b) downward fluxes from the 2- to 7-km layer into the boundary layer. The two values in each grid cell are the lower and the upper limits of the fluxes.

Loss of boundary layer $\mathrm{CO}$ through oxidation by $\mathrm{OH}$ is estimated from

$$
d[\mathrm{CO}] / d t=-k_{4}[\mathrm{CO}][\mathrm{OH}]
$$

where $k_{4}$ is the rate constant for the reaction of $\mathrm{CO}$ with $\mathrm{OH}$. The same model estimate of $[\mathrm{OH}]$ as in (3) was used. This computation yields a $\mathrm{CO}$ loss over the region of $8.6 \times 10^{8} \mathrm{~kg}$ month $^{-1}$.

\subsection{Horizontal Fluxes}

We used gridded monthly mean $u$ and $v$ wind components taken from a 1980-1987 climatology [Schubert et al., 1990] of analyses from the European Centre for Medium-Range Weather Forecasts (ECMWF) to estimate the boundary layer horizontal flux of $\mathrm{CO}$ into and out of the region. The 
Table 3. Horizontal Fluxes of $\mathrm{CO}$

\begin{tabular}{cc}
$\begin{array}{c}\text { Regional } \\
\text { Boundary }\end{array}$ & $\begin{array}{c}\text { Horizontal Flux, } \\
\mathbf{1 0}^{8} \text { }^{-} \text {month }^{-1}\end{array}$ \\
\hline North & 1.9 \\
West & 21.7 \\
South & 31.3 \\
East & -26.7 \\
\hline
\end{tabular}

Note that positive values indicate flux into region; negative values indicate flux out of the region.

ECMWF winds from approximately the bottom and top of the boundary layer (1000 and 850 mbar, except for surface and 700 mbar on high-terrain western edge) were averaged for use in this calculation. A horizontal flux was computed for each $2.5^{\circ} \times 2.5^{\circ}$ grid cell on the borders of the region, assuming that the $\mathrm{CO}$ mixing ratio (Figure 3a) is an appropriate estimate of the $\mathrm{CO}$ content of the air entering or leaving the region through the outer boundary of that cell. Horizontal flux values for all boundary grid cells having mean winds advecting $\mathrm{CO}$ into the region are summed, as are values for all boundary grid cells having mean winds advecting $\mathrm{CO}$ out of the region. It turns out that there is a net $\mathrm{CO}$ convergence in the boundary layer over the region in the
Table 4. Comparison of GSFC and Harvard/GISS Regional Boundary Layer CO Budgets

\begin{tabular}{lrc}
\hline \multicolumn{1}{c}{ Component } & GSFC & Harvard/GISS* \\
\hline Surface flux ${ }^{\dagger}$ & 6.9 & 11.3 \\
Net production (P-L) & -0.8 & 3.9 \\
Net horizontal flux & 28.2 & 42.1 \\
Net vertical flux & -34.3 & -56.6 \\
\hline
\end{tabular}

Note that all values are in $10^{8} \mathrm{~kg}_{\text {month }}{ }^{-1}$. GSFC, Goddard Space Flight Center; GISS, Goddard Institute for Space Studies; NAPAP, National Acid Precipitation Assessment Program.

*Values are averaged over June, July, and August. Harvard/GISS domain has $25 \%$ greater area than GSFC region. Harvard/GISS boundary layer has 2.6-km depth, and GSFC depth is $1.5 \mathrm{~km}$.

tGSFC value includes NAPAP anthropogenic emissions, biogenic emissions, and surface deposition; Harvard/GISS value is NAPAP anthropogenic emissions.

month of June. The net horizontal fluxes on each side of the region are given in Table 3. Those across the southern and western boundaries are particularly significant. The total horizontal flux of boundary layer $\mathrm{CO}$ into the region $\left(F_{i}\right)$ is $54.9 \times 10^{8} \mathrm{~kg}$ month ${ }^{-1}$ and the $\mathrm{CO}$ flux out of the region is $26.7 \times 10^{8} \mathrm{~kg} \mathrm{month}^{-1}$, yielding a net influx of $28.2 \times 10^{8} \mathrm{~kg}$ month $^{-1}$.

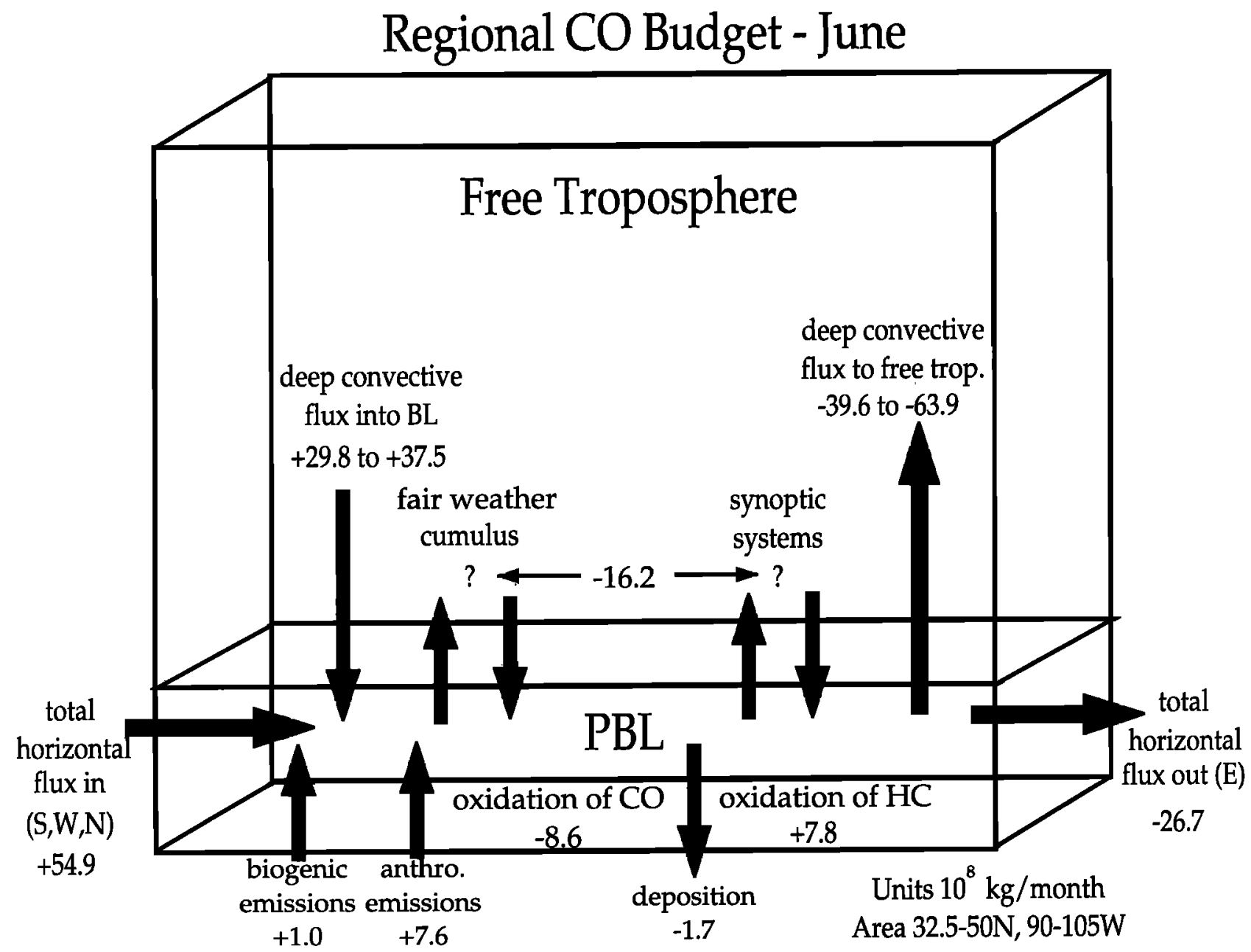

Figure 5. Regional boundary layer $\mathrm{CO}$ budget for the central United States. Components of "total horizontal flux in" are given in Table 3. Question marks signify that relative amounts of CO flux due to shallow convection and synoptic-scale systems are unknown. 


\subsection{Total Regional CO Budget}

Figure 5 summarizes the boundary layer $\mathrm{CO}$ budget for central United States in June. The upward deep convective flux, $F_{u}$, is one of the largest components; the downward flux from the middle troposphere to the boundary layer, $F_{d}$, is somewhat less than $F_{u}$ but is still substantial. Using the midpoints of the ranges of $F_{u}$ and $F_{d}$, we compute a net deep convective flux, $F_{u \text {, net }}$, of $18.1 \times 10^{8} \mathrm{~kg}$ month $^{-1}$ from the boundary layer. Taking the extremes of $F_{u}$ and $F_{d}$ would lead to a range for $F_{u, \text { net }}$ of $9.8-26.4 \times 10^{8} \mathrm{~kg} \mathrm{month}^{-1}$. However, values from two of the three transport events are close to the high end of the range, so we believe that the midpoint estimate for $F_{u \text {, net }}$ is conservative. This is also consistent with the apparent underestimate in the ISCCP deep convective cloud cover climatology.

Totaling the sources and sinks of the boundary layer $\mathrm{CO}$ budget for the region yields a total source of $104.9 \times 10^{8} \mathrm{~kg}$ month ${ }^{-1}$ and a total sink of $88.7 \times 10^{8} \mathrm{~kg}$ month $^{-1}$. These totals were computed using the midpoints of the $F_{u}$ and $F_{d}$ ranges. Additional sinks, $R$ in (1), are required to balance the regional boundary layer $\mathrm{CO}$ budget. It is assumed that these are the other major boundary layer venting processes, shallow cumulus clouds and synoptic-scale frontal weather systems, and their combined net flux is the difference between the total source and the total sinks: $16.2 \times 10^{8} \mathrm{~kg}$ month $^{-1}$. Note that this is about the same magnitude as the net deep convective sink $F_{u \text {, net }}\left(18.1 \times 10^{8} \mathrm{~kg}\right.$ month $\left.^{-1}\right)$. We do not expect significant large-scale (nonconvective) venting by synoptic-scale systems during June over the central United States because these systems are relatively weak and less frequent in summer. Fields of daytime shallow cumulus clouds are frequent over parts of the region, but the fraction of these clouds actively venting material from boundary layer to free troposphere is usually quite small [Stull, 1985]. Therefore the dominance of deep convection as a venting mechanism over the central United States during June is reasonable. The total boundary layer venting $\left(34.3 \times 10^{8} \mathrm{~kg}\right.$ month ${ }^{-1}$ ) is particularly significant when compared with the total NAPAP CO emissions for the United States of $51 \times 10^{8}$ $\mathrm{kg}$ month $^{-1}$. Thus the central United States may be considered a "chimney" for the country.

We compare our regional $\mathrm{CO}$ budget with that derived for a similar region $\left(32^{\circ}-48^{\circ} \mathrm{N}, 87.5^{\circ}-107.5^{\circ} \mathrm{W}\right)$ from a summertime simulation with a three-dimensional model [Jacob et al., 1993b]. Results for both budgets are summarized in Table 4. The simulation was performed with a threedimensional continental-scale photochemical model using a $4^{\circ}$ latitude by $5^{\circ}$ longitude grid with nine layers in the vertical. This grid matches that of the Goddard Institute for Space Studies (GISS) general circulation model (GCM2). The photochemical model was run with a one-summer archive of data from GCM2 as input. Net photochemical production of $\mathrm{CO}$ is near zero in both the GSFC and Harvard/GISS budgets, reflecting the fact that $\mathrm{OH}$ number densities are similar in both approaches. The top of the boundary layer in the model $(2.6 \mathrm{~km})$ is somewhat higher than we have assumed $(1.5 \mathrm{~km})$, and the area considered in the model is $25 \%$ larger than our region. We have scaled the Harvard/GISS net vertical flux to our regional area. After scaling, this value $\left(45.3 \times 10^{8} \mathrm{~kg} \mathrm{month}^{-1}\right)$ is slightly larger than our net vertical $\mathrm{CO}$ flux. A possible explanation for the difference may be that the deeper boundary layer allows more horizontal convergence in the Harvard/GISS model.

\section{Convective Flux Contribution to the Regional $\mathrm{O}_{3}$ Budget}

The CO budget is important because $\mathrm{CO}$ controls the odd hydrogen radical balance, producing $\mathrm{HO}_{2}$ through the reaction of $\mathrm{CO}$ with $\mathrm{OH}$. Reaction of $\mathrm{HO}_{2}$ with $\mathrm{NO}$ leads to $\mathrm{NO}_{2}$, then photochemical $\mathrm{O}_{3}$ production [Crutzen, 1973; Chameides and Walker, 1973]. The relative importance of $\mathrm{CO}$ in $\mathrm{O}_{3}$ formation depends on the relative distribution of $\mathrm{CO}$, organic radicals (generally $\mathrm{RO}_{2}$ ), and $\mathrm{NO}$ because $\mathrm{RO}_{2}$ also converts $\mathrm{NO}$ to $\mathrm{NO}_{2}$, producing $\mathrm{O}_{3}$. The influence of most reactive NMHCs does not extend far from source regions, but $\mathrm{CO}$ with a lifetime of $\sim 1$ month can be transported long distances after venting to the free troposphere.

We have attempted to calculate the free tropospheric $\mathrm{O}_{3}$ production that results from deep convective venting over the central United States. The challenge in doing this is that $\mathrm{O}_{3}$ production in the region is $\mathrm{NO}_{x}$ limited. Although boundary layer venting frequently dilutes $\mathrm{NO}_{x}$ and increases the efficiency of $\mathrm{O}_{3}$ production [Liu et al., 1987], it is difficult to apply the statistical-dynamical approach to a regional deep convective flux for $\mathrm{NO}_{x}$. The $\mathrm{NO}_{x}$ lifetime is only a few hours and there are not sufficient high-quality $N O_{x}$ observations over the central United States. Therefore existing one-dimensional model calculations of postconvection $\mathrm{O}_{3}$ production for the June 10 and 26, 1985, PRESTORM episodes are used to estimate the consequences of deep convective venting for $\mathrm{O}_{3}$ formation over the central United States [Pickering et al., 1992b]. The boundary layer in these two events was assumed to have 0.9 ppbv $\mathrm{NO}_{x}$, a value typical for the region. Upward convective transport from the boundary layer increased $\mathrm{NO}_{x}$ by an average $0.3 \mathrm{ppbv}$ in the free troposphere. The mean free tropospheric diurnally averaged gross $\mathrm{O}_{3}$ production rate in cloud-processed air for the first 24 hours after these events increased by $7.97 \times 10^{11}$ molecules $\mathrm{cm}^{-2} \mathrm{~s}^{-1}$ over the rate in undisturbed air. We extrapolate this incremental rate to the central United States by multiplying by the area $\left(2.428 \times 10^{6} \mathrm{~km}^{2}\right)$ and by the fraction of area with cloud-processed air. Typical June middle to upper tropospheric wind speeds over the region suggest that cloud outflow plumes extend over an area 3-5 times as large as the convective regions themselves at the end of 24 hours of transport. If this factor is applied to the area defined by ISCCP as deep convective cloud cover (7.9\%), the area appropriate for our postconvective $\mathrm{O}_{3}$ rate is $5.75-9.59 \times 10^{5} \mathrm{~km}^{2}$. Multiplying the two terms yields a gross production rate due to deep convection of $0.66-1.1$ $\mathrm{Gmol} \mathrm{O}_{3} \mathrm{~d}^{-1}$ for the free troposphere over the region. This may be a minimum because of the probable underestimate of deep convective cloud cover by ISCCP. On the other hand, note that this estimate is more uncertain than the $\mathrm{CO}$ deep convective flux because we have extrapolated from a few events and assumed mean convective cloud cover instead of averaging over individual grid cells.

Jacob et al. [1993a] estimated a gross $\mathrm{O}_{3}$ production rate of $4 \mathrm{Gmol} \mathrm{d}^{-1}$ due to $\mathrm{O}_{3}$ precursors exported out of the boundary layer of the contiguous United States in summer. They obtained that estimate by scaling the $\mathrm{NO}_{x}$ export of $0.07 \mathrm{Gmol} \mathrm{d}^{-1}$ computed in their three-dimensional model with an $\mathrm{O}_{3}$ production efficiency of 57 derived from a 
photochemical mechanism. Of the total $\mathrm{NO}_{x}$ export in their three-dimensional model, $30 \%$ took place over the central United States as defined here, corresponding to an $\mathrm{O}_{3}$ production of $1.2 \mathrm{Gmol} \mathrm{d}^{-1}$ in the free troposphere. The $\mathrm{NO}_{x}$ export in their model includes boundary layer venting from all mechanisms. Our estimate for the deep convective transport mechanism $\left(0.66-1.1 \mathrm{Gmol} \mathrm{d}^{-1}\right)$ is remarkably close $(\sim 55-90 \%)$ to the value from the three-dimensional model. It is also consistent with a CO budget that shows net upward deep convective transport at slightly more than half of the total net CO upflux (compare $F_{u, \text { net }}$ and $R$ ). The analysis by Chin et al. [1994], showing that the Harvard/ GISS three-dimensional model closely reproduces the observed $\mathrm{O}_{3}-\mathrm{CO}$ correlation and slope for most rural U.S. measurement sites, lends confidence to the Jacob et al. [1993a] $\mathrm{O}_{3}$ production rates and to those estimated here.

\section{Summary}

A regional budget for boundary layer $\mathrm{CO}$ has been constructed for the central United States in early summer. The single largest term, the deep convective upward flux, is calculated using a statistical-dynamical approach, from measured $\mathrm{CO}$ mixing ratios, cloud model transport statistics, and the ISCCP cloud climatology. Other components of the boundary layer $\mathrm{CO}$ budget are evaluated using archived emission inventories, climatological data, and photochemical modeling. Downward convective transport from the free troposphere to the boundary layer reduces the net upward convective $\mathrm{CO}$ flux to a value comparable to what appears to be the sum of net fluxes from active shallow cumulus clouds and frontal systems. However, deep convection is more effective at creating conditions for rapid $\mathrm{O}_{3}$ formation and $\mathrm{O}_{3}$ precursors are transported to higher altitudes.

Production of $\mathrm{CO}$ from oxidation of hydrocarbons over the region is approximately balanced by loss of $\mathrm{CO}$ through oxidation by $\mathrm{OH}$. The combination of all three venting mechanisms essentially balances regional anthropogenic $\mathrm{CO}$ emissions and the net horizontal flux of $\mathrm{CO}$ into the region. The $\mathrm{CO}$ budget derived here compares favorably with a budget estimated for the same region with the Harvard/GISS three-dimensional chemical transport model. Venting (total of $34.3 \times 10^{8} \mathrm{~kg} \mathrm{month}^{-1}$ ) of the boundary layer over the region prevents large accumulations of $\mathrm{CO}$ which would be advected within the boundary layer to the eastern United States and Canada. Indeed, typical rural boundary layer CO mixing ratios in the eastern United States and Canada [e.g., Parrish et al., 1993; Poulida et al., 1991; Ryan et al., 1993] are not much greater than those in the central United States. The large amount of $\mathrm{CO}$ vented from the boundary layer in this region implies that the central United States acts as a "chimney." for the country. On the other hand, boundary layer venting results in substantial amounts of $\mathrm{O}_{3}$ and $\mathrm{O}_{3}$ precursors in the free troposphere being transported off the North American continent. Deep convective venting of $\mathrm{CO}$ over the central United States can produce $\sim 1 \mathrm{Gmol} \mathrm{O}_{3} \mathrm{~d}^{-1}$ in the free troposphere in early summer. Jacob et al. [1993a] estimates that on average all boundary layer venting processes over the continental United States in summer are a major source of free tropospheric $\mathrm{O}_{3}$ formation, comparable to injection of $\mathrm{O}_{3}$ from the stratosphere [e.g., Danielson and Mohnen, 1977].

We comment on generalizing the methods of this paper to other species and regions. The central United States has been ideal for an initial $\mathrm{CO}$ budget study because representative trace gas measurements from surface and aircraft are available for both urban and rural regions and we had built up a base of cloud-scale transport statistics from deep convective episodes. In general, $\mathrm{CO}$ is amenable to the analysis presented here in any region with detailed emission inventories, representative trace gas measurements, and meteorological data adequate for cloud model simulations of prototype convective events. It is less appropriate to attempt a budget for short-lived species (i.e., more spatially variable) with more complex chemistry. In the case of $\mathrm{CO}$ we plan to calculate regional budgets during the southern hemisphere 1992 biomass burning season from satellite imagery of clouds and fires and from chemical and meteorological observations taken during the Southern African Fire Atmospheric Regional Initiative (SAFARI) and Global Tropospheric Experiment/Transport and Atmospheric Chemistry near the Equator-Atlantic (GTE/TRACE-A) field campaigns.

Acknowledgments. This work was supported under the U.S. Environmental Protection Agency (U.S. EPA) Global Tropospheric Chemistry Program through Interagency Agreement 5678 to GSFC and under the U.S. EPA Office of Exploratory Research through grant R-814526-02-1 to the University of Maryland. RRD was supported by the Center for Clouds, Chemistry and Climate. DJJ's work was supported by the National Science Foundation (grant ATM-9304217). We thank the U.S. Air Force Air Weather Service Environmental Technical Applications Center for summarizing the RTNEPH convective cloud data.

\section{References}

Boatman, J. F., D. L. Wellman, C. C. Van Valin, R. L. Gunter, J. D. Ray, H. Sievering, Y. Kim, S. W. Wilkison, and M. Luria, Airborne sampling of selected trace chemicals above the central United States, J. Geophys. Res., 94, 5081-5093, 1989.

Buhr, M. P., M. Trainer, D. D. Parrish, R. E. Sievers, and F. C. Fehsenfeld, Assessment of pollutant emission inventories by principal component analysis of ambient air measurements, Geophys. Res. Lett., 19, 1009-1012, 1992.

Chameides, W., and J. C. G. Walker, A photochemical theory of tropospheric ozone, J. Geophys. Res., 78, 8751-8760, 1973.

Chin, M., D. J. Jacob, J. W. Munger, D. D. Parrish, and B. G. Doddridge, Relationship of ozone and carbon monoxide over North America and its implication for ozone production and transport, J. Geophys. Res., 99, 14,565-14,573, 1994.

Crutzen, P. J., A discussion of the chemistry of some minor constituents in the stratosphere and troposphere, Pure Appl. Geophys., 106-108, 1385-1399, 1973.

Danielson, E. F., and V. Mohnen, Project Duststorm: Ozone transport, in situ measurements, and meteorological analysis of tropopause folding, J. Geophys. Res., 82, 5867-5877, 1977.

Dickerson, R. R., and A. C. Delany, Modification of a commercial gas filter correlation $\mathrm{CO}$ detector for enhanced sensitivity, $J$. Atmos. Oceanic Technol., 5, 424-431, 1988.

Dickerson, R. R., et al., Thunderstorms: An important mechanism in the transport of air pollutants, Science, 235, 460-465, 1987.

Dickerson, R. R., B. G. Doddridge, O. Poulida, and M. A. Owens, The gradient of meteorological and chemical variables across the tropopause, in Ozone in the Troposphere and Stratosphere, edited by R. D. Hudson, NASA Conf. Publ. 3266, in press, 1994.

Fishman, J., C. E. Watson, J. C. Larsen, and J. A. Logan, The distribution of tropospheric ozone determined from satellite data, J. Geophys. Res., 95, 3599-3617, 1990.

Hanst, P. L., J. W. Spence, and E. O. Edney, Carbon monoxide production in photooxidation of organic molecules in the air, Atmos. Environ., 14, 1077-1088, 1980.

Holzworth, G. C., Estimates of mean mixing depths in the contiguous United States, Mon. Weather Rev., 92, 235-247, 1964.

Jacob, D. J., J. A. Logan, G. M. Gardner, R. M. Yevich, C. M. 
Spivakovsky, S. C. Wofsy, S. Sillman, and M. J. Prather, Factors regulating ozone over the United States and its export to the global atmosphere, J. Geophys. Res., 98, 14,817-14,826, 1993a.

Jacob, D. J., et al., Simulation of summertime ozone over North America, J. Geophys. Res., 98, 14,797-14,816, 1993b.

Kirchhoff, V. W. J. H., and E. V. A. Marinho, Surface carbon monoxide measurements in Amazonia, J. Geophys. Res., 95, $16,933-16,944,1990$.

Klein, S. A., and D. L. Hartmann, Spurious changes in the ISCCP dataset, Geophys. Res. Lett., 20, 455-458, 1993.

Liu, S. C., M. Trainer, F. C. Fehsenfeld, D. D. Parrish, E. J. Williams, D. W. Fahey, G. Hubler, and P. C. Murphy, Ozone production in the rural troposphere and the implications for regional and global ozone distributions, J. Geophys. Res., 92, 4191-4207, 1987.

Luke, W. T., Reactive nitrogen compounds in the troposphere: Observations, transport, and photochemistry, $\mathrm{Ph} . \mathrm{D}$. dissertation, Dep. of Chem., Univ. of Maryland, College Park, 1990.

Luke, W. T., R. R. Dickerson, W. F. Ryan, K. E. Pickering, and L. J. Nunnermacker, Tropospheric chemistry over the lower Great Plains of the United States, 2, Trace gas profiles and distributions, J. Geophys. Res., 97, 20,647-20,670, 1992.

Lurmann, F. W., A. C. Lloyd, and R. Atkinson, A chemical mechanism for use in long-range transport/acid deposition computer modeling, J. Geophys. Res., 91, 10,905-10,936, 1986.

Matthews, E., Global vegetation and land use: New high-resolution database for climate studies, J. Clim. Appl. Meteorol., 22, 474 487, 1983.

Parrish, D. D., J. S. Holloway, M. Trainer, P. C. Murphy, G. L. Forbes, and F. C. Fehsenfeld, Export of North American ozone pollution to the North Atlantic Ocean, Science, 259, 1436-1439, 1993.

Pickering, K. E., R. R. Dickerson, G. J. Huffman, J. F. Boatman, and A. Schanot, Trace gas transport in the vicinity of frontal convective clouds, J. Geophys. Res., 93, 759-773, 1988.

Pickering, K. E., R. R. Dickerson, W. T. Luke, and L. J. Nunnermacker, Clear-sky vertical profiles of trace gases as influenced by upstream convective activity, J. Geophys. Res., 94, 14,879$14,892,1989$.

Pickering, K. E., A. M. Thompson, R. R. Dickerson, W. T. Luke, D. P. McNamara, J. P. Greenberg, and P. R. Zimmerman, Model calculations of tropospheric ozone production potential following observed convective events, J. Geophys. Res., 95, 14,049-14,062, 1990.

Pickering, K. E., J. R. Scala, A. M. Thompson, W.-K. Tao, and J. Simpson, A regional estimate of convective transport of CO from biomass burning, Geophys. Res. Lett., 19, 289-292, 1992a.

Pickering, K. E., A. M. Thompson, J. R. Scala, W.-K. Tao, R. R. Dickerson, and J. Simpson, Free tropospheric ozone production following entrainment of urban plumes into deep convection, $J$. Geophys. Res., 97, 17,985-18,000, 1992b.

Pierson, W. R., A. W. Gertler, and R. L. Bradow, Comparison of the SCAQS tunnel study with other on-road vehicle emission data, J. Air Waste Manage. Assoc., 40, 1495-1504, 1990.

Placet, M., et al., Emissions involved in acidic deposition processes, in State of Science and Technology Report 1, National Acid Precipitation Assessment Program, Washington, D. C., 1990.

Poulida, O., and R. R. Dickerson, Troposphere-stratosphere exchange in a mesoscale convective system, Eos Trans. AGU, 74(16), Spring Meeting suppl., 73, 1993.

Poulida, O., R. R. Dickerson, B. G. Doddridge, J. Z. Holland, R. G. Wardell, and J. G. Watkins, Trace gas concentrations and mete- orology in rural Virginia, 1 , Ozone and carbon monoxide, $J$. Geophys. Res., 96, 22,461-22,475, 1991.

Rasmusson, E. M., Diurnal variation of summertime thunderstorm activity over the United States, Tech. Note 71-4, U.S. Air Force Environ. Tech. Appl. Cent., Scott AFB, Ill., 1971.

Ritter, J. A., J. D. W. Barrick, C. E. Watson, G. W. Sachse, G. L. Gregory, B. E. Anderson, M. A. Woerner, and J. E. Collins Jr., Airborne boundary layer flux measurements of trace species over Canadian boreal forest and northern wetland regions, J. Geophys. Res., 99, 1671-1685, 1994.

Rossow, W. B., and R. A. Schiffer, International Satellite Cloud Climatology Project (ISCCP) cloud data products, Bull. Am. Meteorol. Soc., 72, 2-20, 1991.

Ryan, W. F., B. G. Doddridge, and R. R. Dickerson, Trace gas profiles in conditions of extreme drought, Eos Trans. AGU, 71, $469,1990$.

Ryan, W. F., P. Kelley, C. Piety, B. G. Doddridge, and R. R. Dickerson, Airborne trace gas observations in support of photochemical modeling in the Baltimore-Washington region, Eos Trans. AGU, 74(16), 71, 1993.

Saeger, M., et al., The 1985 NAPAP emissions inventory (version 2): Development of the annual data and modelers' tapes, $E P A$ Rep., EPA-600/7-89-012a, U.S. Environ. Prot. Agency, Research Triangle Park, N. C., 1989.

Scala, J. R., K. E. Pickering, W.-K. Tao, J. Simpson, and R. R. Dickerson, Convective transport of tracers by midlatitude squalltype mesoscale convective systems (Preprints), in Conference on Atmospheric Chemistry, Am. Meteorol. Soc., Anaheim, Calif., 1993.

Schubert, S., C.-K. Park, W. Higgins, S. Moorthi, and M. Suarez, An atlas of ECMWF analyses, NASA Tech. Memo. 100747, 273 pp., 1990.

Seiler, W., The cycle of atmospheric CO, Tellus, 26, 118-135, 1974. Stull, R. B., A fair-weather cumulus cloud classification scheme for mixed-layer studies, J. Clim. Appl. Meteorol., 24, 49-56, 1985.

Tao, W.-K., and J. Simpson, Goddard cumulus ensemble model, I, Model description, Terr. Atmos. Oceanic Sci., 4, 35-71, 1993.

Tao, W.-K., J. Simpson, C.-H. Sui, B. Ferrier, S. Lang, J. Scala, M.-D. Chou, and K. Pickering, Heating, moisture, and water budgets of tropical and midlatitude squall lines: Comparisons and sensitivity to longwave radiation, J. Atmos. Sci., 50, 673-690, 1993.

Zimmerman, P. R., R. B. Chatfield, J. Fishman, P. J. Crutzen, and P. L. Hanst, Estimates on the production of $\mathrm{CO}$ and $\mathrm{H}_{2}$ from the oxidation of hydrocarbon emissions from vegetation, Geophys. Res. Lett., 5, 679-682, 1978.

R. R. Dickerson and W. G. Ellis Jr., Department of Meteorology, University of Maryland, College Park, MD 20742.

D. J. Jacob, Division of Applied Sciences and Department of Earth and Planetary Sciences, Harvard University, Cambridge, MA 02138.

D. P. McNamara, Applied Research Corporation, Landover, MD 20785.

K. E. Pickering and J. R. Scala, Universities Space Research Association, Laboratory for Atmospheres, NASA/GSFC, Greenbelt, MD 20771.

J. Simpson, W.-K. Tao, and A. Thompson, NASA Goddard Space Flight Center, Mail Code 916, Greenbelt, MD 20771.

(Received October 20, 1993; revised March 31, 1994; accepted May 4, 1994.) 